\title{
Pengaruh Cash Ratio, Debt to Equity Ratio, dan Return On Assets Terhadap Return Saham dengan Nilai Tukar sebagai Variabel Moderating Pada Perusahaan Perkebunan yang Terdaftar di Bursa Efek Indonesia (BEI) Periode 2014-2018
}

\author{
Yunan Surono $^{1 *}$, Andrian Hadinata ${ }^{2}$ \\ ${ }^{1}$ Dosen Fakultas Ekonomi Universitas Batanghari Jambi \\ ${ }^{2}$ Mahasiswa Fakultas Ekonomi Prodi Manajemen Keuangan Universitas Batanghari Jambi \\ "Corresponding email: suronoyunan@gmail.com, ${ }^{2}$ andrian.hadinata1@gmail.com
}

\begin{abstract}
The purpose of the research is to analyze the Influence of Cash Ratio, Debt To Equity Ratio and Return On Assets to Stock Return With Exchange Rate as Moderating Variables In Plantation Companies Listed In Indonesia Stock Exchange. This research uses descriptive analysis and statistical analysis methods. data that uses secondary data. This study focuses on the influence of 3 independent variables on the dependent variable by adding moderation variables to determine whether the moderating variable can affect the relationship between the independent variables on the dependent variable. Hypothesis testing in this study uses the $F$ test and t test, with a brief significance level (a) 5\%. This data analysis uses SPSS 20 data processing software for Windows. The population of this study is companies engaged in the plantation sector in the Indonesia Stock Exchange period 2014 - 2018, with a purposive sampling technique, obtained 6 companies that have fullfill criteria in this research. The results of this study partially Cash Ratio, Debt to Equity Ratio, and Return On Assets have a significant effect on stock returns, partially Debt to Equity Ratio and Return On Assets have a significant positive effect on stock returns, while Cash Ratio has no significant effect on stock returns. and the value is not able to affect the relationship between independent variable and dependent variable.
\end{abstract}

Keywords: Cash Ratio, Debt to Equity Ratio, Return On Assets, Stock Returns, Moderation Variables, Exchange Rates.

\section{Pendahuluan}

Sektor pertanian mempunyai peranan cukup penting dalam kegiatan perekonomian Indonesia. Hal ini dapat dilihat dari kontribusinya terhadap produk domestik bruto (PDB) yang cukup besar yaitu sekitar 13,14 persen pada tahun 2017 atau merupakan urutan kedua setelah sektor industri pengolahan. Pada tahun 2016 nilai ekspor pertanian sebesar US\$ 3.354,8 juta dan pada tahun 2017 meningkat mejadi US\$ 3.671,0 juta (BPS, 2017). Dengan potensi yang besar dan masih dapat berkembang, industri perkebunan memerlukan modal yang besar untuk melakukan ekspansinya. Salah satu cara untuk meningkatkan modal adalah dengan cara menawarkan sahamnya pada investor melalui pasar modal.

Pasar modal sendiri merupakan pasar untuk berbagai instrument keuangan jangka Panjang yang bisa diperjual belikan, baik surat utang (obligasi), ekuitas (saham), reksa dana, serta instrument investasi lainnya. Pasar modal merupakan sarana pendanaan bagi perusahaan maupun institusi lain. Dengan demikian pasar modal memfasilitasi bebragai sarana dan prasarana kegiatan jual beli dan kegiatan terkait lainnya. Dalam melakukan investasi, terdapat dua teknik dalam menganalisis yaitu, analisis teknikal dan analisis fundamental. Analisis teknikal merupakan pendekatan investasi dengan cara mempelajari data histori dari harga saham serta menghubungkan dengan trading volume yang terjadi dan kondisin ekonomi saat itu. sedangkan analisis fundamental adalah analisis yang menitik beratkan pada kinerja perusahaan yang mengeluarkan saham dan analisis ekonomi yang akan mempengaruhi masa depan perusahaan. Untuk melakukan analisis fundamental mengenai kemampuan perusahaan investor dalam mengukur kinerja suatu perusahaan dengan laporan keuangan sebagai sumber informasi. Laporan keuangan merupakan gambaran kondisi keuangan dan hasil usaha suatu perusahaan pada saat tertentu atau jangka waktu tertentu. Laporan keuangan merupakan merupakan media yang paling penting bagi investor untuk mengukur kinerja dan kondisi keuangan suatu perusahaan. Laporan keuangan yang biasa dikenal adalah neraca, laba rugi, arus kas, dan posisi keuangan.

Analisis fundamental terdapat berbagai rasio keuangan merupakan kegiatan membandingkan angka-angka yang ada dalam laporan keuangan dengan cara membagi satu angka dengan angka lainnya. Rasio keuangan sendiri terdiri dari 5 rasio yaitu rasio likuiditas, rasio leverage, rasio aktivitas, rasio profitabilitas, rasio penilaian/ rasio pasar. Dalam penelitian rasio yang digunakan adalah rasio likuiditas, rasio leverage, dan rasio profitabilitas, karena rasio ini merupakan sebagai bahan pertimbangan bagi investor dalam berivestasi. Selain dari faktor fundamental yang berasal dari dalam perusahaan, faktor makro juga dapat mempengaruhi kinerja suatu perusahaan. Faktor makro merupakan faktor yang berada di luar perusahaan. Faktor makro yang mempengaruhi kinerja suatu perusahaan secara langsung adalah nilai tukar mata uang. Nilai tukar mata uang merupakan nilai tukar suatu mata uang yang timbul akibat kegiatan jual beli pada pasar valuta asing. 
Yunan Surono dan Andrian Hadinata, Pengaruh Cash Ratio, Debt to Equity Ratio, dan Return On Assets Terhadap Return Saham dengan Nilai Tukar sebagai Variabel Moderating Pada Perusahaan Perkebunan yang Terdaftar di Bursa Efek Indonesia (BEI) Periode 2014-2018

Nilai tukar sangat penting untuk diperhatikan, karena hal tersebut sangat mempengaruhi biaya yang dikeluarkan oleh perusahaan, terutama perusahaan yang melakukan pinjaman dalam valuta asing dan melakukan kegiatan ekspor impor. Ketika nilai tukar rupiah mengalami pelemahan maka perusahaan yang memiliki utang dalam valuta asing dan yang berbasis impor akan mengalami permasalahan dalam biaya. Fluktuasi nilai tukar yang tidak stabil akan menjadi pertimbangan bagi investor karena sulitnya mengontrol biaya-biaya yang timbul akibat nilai tukar sehingga kinerja perusahaan akan semakin sulit pula. Dalam melakukan investasi, investor memiliki beberapa pertimbangan kriteria, diantaranya perusahaan yang memiliki kemampuan/potensial untuk menghasilkan return/keuntungan, salah satu komponen dari return sendiri adalah capital gain. Capital gain merupakan selisih harga jual saham dengan harga beli saham Return merupakan hasil yang diperoleh dari investasi, return dapat berupa ekspetasi yang sudah terjadi atau return ekspetasi yang belum terjadi tetapi yang diharapkan akan terjadi dimasa yang akan datang. Dalam hal ini jumlah yang diinvestasikan merupakan harga saham yang dibeli dan jumlah yang diterima merupakan harga saham dalam perdagangan saham. Harga saham sendiri setiap waktunya berubah selama terjadi kegiatan dalam pasar modal. Apabila perubahan harga saham meningkat maka investor akan menerima laba atau untung akan tetapi apabila perubahan harga saham menurun maka investor akan mengalami kerugian atas selisih harga saham saat ini dengan saat dibeli.

\section{Metode}

Metode penelitian yang akan digunakan dalam penelitian ini adalah menggunakan penelitian kuantitatif. Metode kuantitatif adalah metode penelitian yang berlandaskan filsafat positivism, digunakan untuk meneliti pada populasi atau sampel tertentu, pengumpulan data menggunakan instrument penelitian, analisis data bersifat kuantitatif/ statistik, dengan tujuan untuk menggambarkan dan menguji hipotesis yang telah ditetapkan (Sugiyono, 2017).

\section{Alat Analisis}

\section{Uji Asumsi Klasik}

a. Uji Normalitas, menurut Silalahi (2018) distribusi normal adalah bentuk distribusi data yang memusat ditengah (mean, mode, dan median ada di tengah). Untuk mendeteksi apakah data berdistribusi normal atau tidak dapat dilakukan dengan menyusun grafik histogram. Kriteria pengujian adalah jika data membentuk kurva simetris (membentuk kurva lonceng) maka data berdistribusi normal.

b. Uji Multikolinearitas, merupakan hubungan linear antar variabel independen di dalam regresi ganda (Silalahi, 2018). Uji Multikolinearitas bertujuan untuk mengetahui apakah model regresi ditemukan adanya korelasi antar variabel bebas. Pengujian dapat dilakukan dengan mencari tolerance value atau VIF (variance inflation factor). Batas VIF adalah dibawah 10 sehingga apabila VIF di bawah 10 berarti model hubungan multivariat antara variabel dinyatakan bebas dari multikolinearitas dan karena itu dapat digunakan analisis multivariat seperti regresi ganda.

c. Uji Autokorelasi, menurut Silalahi (2018), uji autokorelasi dapat menggunakan uji Durbin-Watson (DW) dengan ketentuan Terjadi autokorelasi positif, jika nilai DW di bawah $1(\mathrm{DW}<1)$, tidak terjadi autokorelasi jika nilai DW berada diantara 1 dan 3 atau $1<\mathrm{DW}<3$, terjadi autokorelasi negatif jika nilai DW diatas 3 .

d. Uji Heteroskedastisitas, menurut Sunyoto (2016), dasar analisis pada uji heteroskedastisitas adalah memakai metode grafik dengan melihat ada tidaknya pola tertentu pada scatterplot dari variabel terkait. Jika ada pola tertentu, dimana titik-titik yang ada membentuk pola tertentu yang teratur (bergelombang, menyebar kemudian menyempit), maka mengindikasikan telah terjadi heteroskedastisitas.

\section{Analisis Regresi Data Panel}

$Y_{i t}=\alpha+\beta_{1} X_{1_{i t}}+\beta_{2} X_{2 i t}+\beta_{3} X_{3 i t}+\varepsilon_{i t}$

Dimana: Yit $=$ Variabel Return Saham; a $=$ Konstanta $($ intercept $) ; \beta 1,2,3=$ Koefisien regresi masing-masing variabel independen; X1 = Variabel Cash Ratio; X2 = Variabel Debt to Equity Ratio; X3 = Variabel Return On Equity; $\varepsilon=$ Error term $; \mathrm{i}=$ data perusahaan; $\mathrm{t}=$ data periode waktu

\section{Analisis Regresi Moderasi (Moderate Regretion Analysis)}

$\mathrm{Y}_{i \mathrm{t}}=\alpha+\beta_{1} \mathrm{X}_{1_{i \mathrm{t}}}+\beta_{2} \mathrm{X}_{2 i \mathrm{t}}+\beta_{3} \mathrm{X}_{3 i \mathrm{t}}+\beta_{4}\left(\mathrm{X}_{1 i \mathrm{t}} \mathrm{Z}\right)+\beta_{5}\left(\mathrm{X}_{2 i \mathrm{t}} \mathrm{Z}\right)+\beta_{6}\left(\mathrm{X}_{3 i \mathrm{t}} \mathrm{Z}\right)+\varepsilon_{i \mathrm{t}}$

Dimana: Yit $=$ Variabel Return Saham; a $=$ Konstanta (intercept); $\beta 1-6=$ Koefisien regresi masing-masing variabel independen; X1 = Variabel Cash Ratio; X2 = Variabel Debt to Equity Ratio; X3 = Variabel Return On Equity; $\varepsilon=$ Error term; $\mathrm{Z}=$ Variabel Nilai Tukar; $\mathrm{i}=$ data perusahaan; $\mathrm{t}=$ data periode waktu

\section{Uji F}

Uji F untuk mengukur pengaruh variabel bebas secara Bersama-sama terhadap variabel tergantung. Hasil uji $\mathrm{F}$ dapat dilihat pada output ANOVA dari hasil analisis linier berganda. Dengan menggunakan tingkat keyakinan 95\%, dan 
$\alpha=5 \%(0,05)$ df 1 (jumlah variabel -1$)$, df $2(n-k-1)$ dimana $n$ adalah jumlah kasus dan $\mathrm{k}$ adalah jumlah variabel independen

\section{Uji $t$}

Uji t digunakan untuk menguji variabel bebas secara parsial terhadap vatiabel tergantung. Hasil uji t dapat dilihat pada output coefficients dari hasil analisis linier berganda. Dimana jika Ho diterima dan Ha ditolak maka tidak ada pengaruh variabel independen terhadap variabel dependen. Serta jika Ho ditolak dan Ha diterima maka terdapat pengaruh antara variabel independen terhadap variabel dependen. Adapun hipotesis penelitian ini adalah:

a. Diduga Cash Ratio, Debt to Equity Ratio, dan Return On Assets berpengaruh signifikan terhadap Return saham.

b. Diduga Cash Ratio, Debt to Equity Ratio, dan Return On Assets berpengaruh signifikan terhadap Return saham.

c. Diduga nilai tukar dapat memoderasi Cash Ratio, Debt to Equity Ratio, dan Return On Assets terhadap Return saham.

\section{Koefisien Determinasi $\left(R^{2}\right)$}

Pada tabel model summary dapat diketahui nilai $\mathrm{R}$ yang menunjukan korelasi antara variabel independen dengan variabel dependen dan nilai koefisien determinasi berganda $\left(R^{2}\right)$ yang memberikan gambaran seberapa besar proporsi atau presentase sumbangan variabel-variabel bebas secara Bersama-sama terhadap perubahan yang terjadi pada variabel-variabel tergantung.

\section{Hasil}

Uji Asumsi Klasik

Uji Normalitas

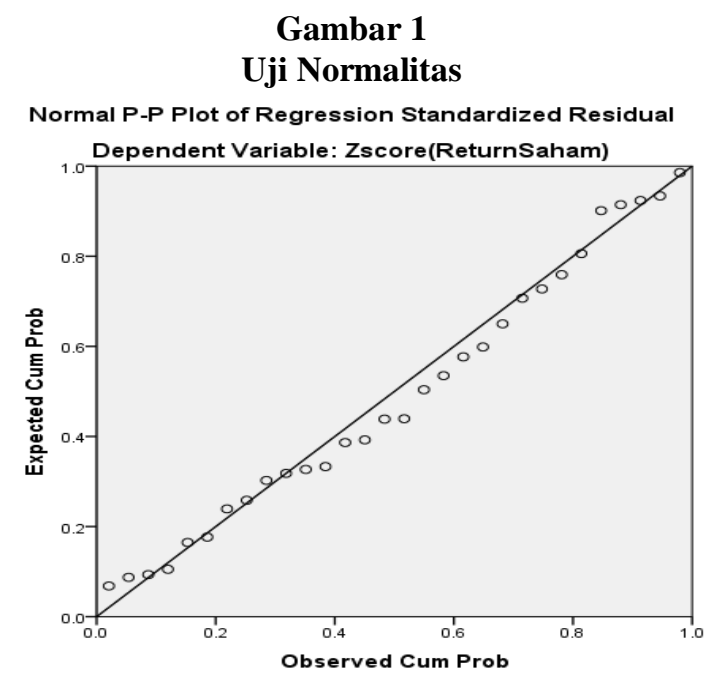

Sumber: data olahan

Gambar 1 hasil uji normalitas P-Plot di atas memperliharkan bahwa nilai observasi dari residu yang distandarisasi berada disekitas garis diagonal sehingga dapat disimpulkan bahwa residu berdistribusi normal.

\section{Uji Multikolinearitas}

Tabel 1

Uji Multikolinearitas

\begin{tabular}{|c|c|c|c|c|c|c|c|}
\hline \multirow{2}{*}{ Model } & \multicolumn{2}{|c|}{ Unstandardized Coefficients } & \multirow{2}{*}{$\begin{array}{l}\text { Standardized Coefficients } \\
\text { Beta }\end{array}$} & \multirow[b]{2}{*}{$t$} & \multirow[b]{2}{*}{ Sig. } & \multicolumn{2}{|c|}{ Collinearity Statistics } \\
\hline & B & Std. Error & & & & Tolerance & VIF \\
\hline$\overline{\text { (Constant) }}$ & -59.024 & 20.896 & & -2.825 & .009 & & \\
\hline CashRatio & .011 & .066 & 029 & .166 & .869 & .829 & 1.206 \\
\hline DebtToEquityRatio & 19.710 & 8.393 & .450 & 2.348 & .027 & .683 & 1.464 \\
\hline ReturnOnAssets & 6.237 & 1.779 & .624 & 3.505 & .002 & .793 & 1.261 \\
\hline
\end{tabular}

Sumber: data olahan 
Berdasarkan hasil uji multikolinearitas dapat diketahui bahwa nilai VIF, dari tabel independen yaitu, Cash Ratio, Debt to Equity Ratio, dan Return On Assets memiliki nilai kurang dari 10. Hal ini menunjukan jika ridak terdapat multikolinearitas antara variabel independen dalam model regresi.

\section{Uji Autokorelasi}

Tabel 2

Uji Autokorelasi

\begin{tabular}{|c|c|c|c|c|}
\hline Model & $\mathbf{R}$ & R square & Adj. R square & DW \\
\hline 1 & .589 & .347 & .272 & 2.072 \\
\hline
\end{tabular}

Sumber: data olahan

Tabel 3 diatas dapat dilihat nilai DW adalah sebesar 2,072 ini berarti dengan melihat kriteria pengambilan keputusan, maka dapat disimpulkan dalam model regresi tidak terjadi autokorelasi karena nilainya berada diantara 1 dan $3(1<\mathrm{DW}<3)$.

\section{Uji Heteroskedastisitas}

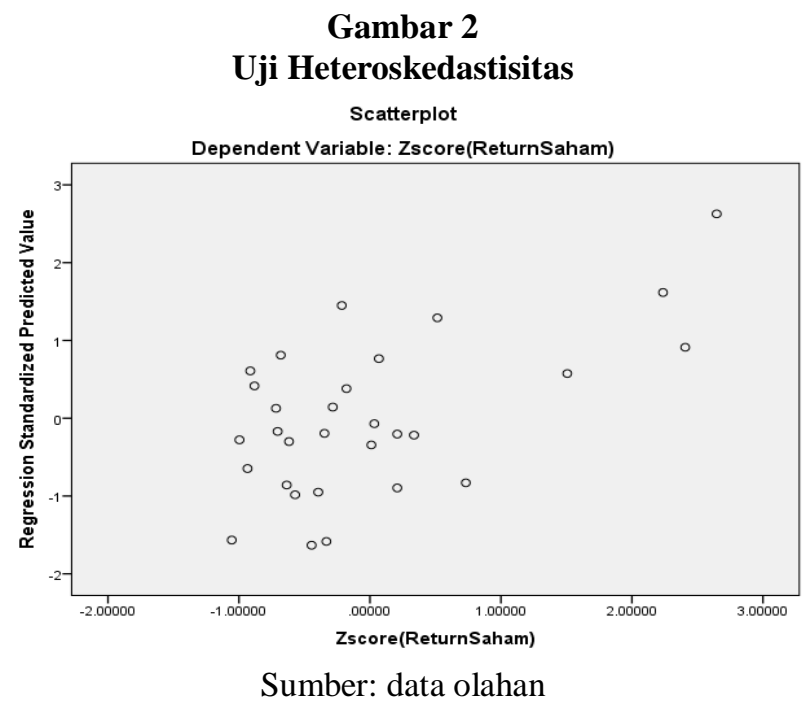

Gambar 2 diatas terlihat bahwa titik-titik menyebar secara acak baik diatas maupun dibawah angka 0 pada sumbu Y dan titik tidak membentuk suatu pola tertentu. Hal ini dapat disimpulkan bahwa tidak terjadi heteroskedastisitas pada model regresi, sehingga model regresi layak untuk memprediksi return saham berdasarkan masukan variabel independeden cash ratio, debt to equity ratio, dan return on assets.

\section{Regresi Linear Berganda}

Berdasarkan Tabel 2 hasil pengujian dengan menggunakan alat analisis berganda diperoleh model regresi sebagai berikut: $\mathrm{Y}=-59,024+0,011 \mathrm{X} 1+19,710 \mathrm{X} 2+6,237 \mathrm{X} 3+\mathrm{e}$

Dari model regresi tersebut dapat dijelaskan:

a. $\alpha=$ konstanta sebesar 59,024, artinya variabel independen yaitu cash ratio, debt to equity ratio, dan return on assets dianggap konstan (bernilai 0), maka variabel dependen yaitu return saham adalah sebesar 59,024.

b. Cash Ratio sebesar 0,011, artinya variabel Cash Ratio mengalami kenaikan sebesar 1 (satu) satuan sedangkan variabel lainnya dianggap konstan, maka variabel dependen yaitu return saham akan mengalami kenaikan sebesar 0,011 .

c. Debt to Equity Ratio sebesar 19,71, artinya variabel Debt to Equity Ratio mengalami kenaikan sebesar 1 (satu) satuan sedangkan variabel lainnya dianggap konstan, maka variabel dependen yaitu return saham akan mengalami kenaikan sebesar 19,71.

Return On Assets sebesar 6,237, artinya variabel Return On Assets mengalami kenaikan sebesar 1 (satu) satuan sedangkan variabel lainnya dianggap konstan, maka variabel dependen yaitu return saham akan mengalami kenaikan sebesar 6,237. 
Yunan Surono dan Andrian Hadinata, Pengaruh Cash Ratio, Debt to Equity Ratio, dan Return On Assets Terhadap Return Saham dengan Nilai Tukar sebagai Variabel Moderating Pada Perusahaan Perkebunan yang Terdaftar di Bursa Efek Indonesia (BEI) Periode 2014-2018

\section{Uji F}

Tabel 3

Uji F

\begin{tabular}{lrrrr}
\hline \multicolumn{1}{c}{ Model } & Sum of Squares & Df & Mean Square & F \\
\hline Regression & 13923.005 & 3 & 4641.002 & 4.607 \\
Residual & 26193.313 & 26 & 1007.435 & \\
Total & 40116.318 & 29 & & \\
\hline
\end{tabular}

Sumber: data olahan

Secara simultan seluruh variabel bebas berpengaruh segnifikan terhadap variabel terkait pada $\alpha=5 \%$ atau 0,05 dan kriteria uji F dengan membandingkan $F_{\text {hitung }}$ sebesar 4,607 dan $F_{\text {tabel }}$ sebesar 2,68, maka dapat dilihat bahwa $F_{\text {hitung }}>F_{\text {tabel }}$ yaitu 4,607 $>2,68$, artinya terdapat pengaruh segnifikan antara variabel cash ratio, debt to equity ratio, dan return on assets, secara simultan terhadap return saham pada perusahaan perkebunan periode $2014-2018$.

Uji t

Uji t digunakan untuk mengetahui apakah variabel independen berpengaruh segnifikan secara parsial terhadap variabel dependen. Tingkat segnifikan menggunakan $\alpha=5 \%$ adalah ukuran standar yang sering digunakan dalam penelitian. Dalam penelitian ini menggunakan uji dua sisi yang dimana $\alpha / 2(0,05 / 2=0,025)$ dengan derajat kebebasan (df) $\mathrm{n}-\mathrm{k}-1$ atau 120-3-1 = 116 ( $\mathrm{n}$ adalah jumlah data $\mathrm{k}$ adalah variabel independen). Maka $t_{\text {tabel }}(\alpha=0,025, \mathrm{df}=116)$ diperoleh sebesar 1,98063. Hasil pengujian Uji t dari penelitian ini dapat dilihat pada Tabel 2. Berdasarkan Tabel 2 tersebut nilai $t_{\text {hitung }}$ dapat diketahui bahwa secara parsial besarnya pengaruh Cash Ratio sebesar 0,166, Debt to Equity Ratio sebesar 2,348 dan Return On Assets sebesar 3,505. Pengujian statistic t dilakukan dengan membandingkan nilai $t_{\text {hitung }}$ dengan $t_{\text {tabel }}$. Dari pengujian maka dapat dijelaskan sebagai berikut:

1. Pengujian Hipotesis Cash Ratio

Nilai $t_{\text {hitung }}$ variabel Cash Ratio sebesar 0,166 dan $t_{\text {tabel }} 1,980$ dari hasil perbandingan maka dapat diketahui $t_{\text {hitung }}<t_{\text {tabel }}(0,166<1,980)$. Dapat dilihat dari signifikan Cash Ratio sebesar 0,869 lebih besar dari $\alpha=0,025$. Maka Ho diterima Ha ditolak artinya tidak ada pengaruh signifikan Cash Ratio secara parsial terhadap laba bersih pada perusahaan perkebunan yang terdaftar di Bursa Efek Indonesia periode 2014 - 2018.

2. Pengujian Hipotesis Debt to Equity Ratio

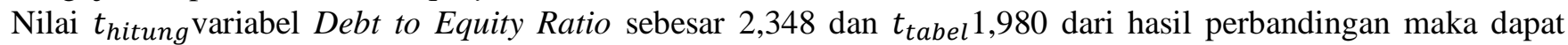
diketahui $t_{\text {hitung }}>t_{\text {tabel }}(2,348>1,980)$. Dapat dilihat dari signifikan Debt to Equity Ratio sebesar 0,027 lebih besar dari $\alpha=0,025$. Maka Ho ditolak Ha diterima artinya Debt to Equity Ratio terdapat pengaruh secara signifikan dan positif secara parsial terhadap laba bersih pada perusahaan perkebunan periode $2014-2018$.

3. Pengujian Hipotesis Return On Assets

Nilai $t_{\text {hitung }}$ variabel Return On Assets sebesar 3,505 dan $t_{\text {tabel }} 1,980$ dari hasil perbandingan maka dapat diketahui $t_{\text {hitung }}>t_{\text {tabel }}(3,505>1,980)$. Dapat dilihat dari signifikan Return On Assets sebesar 0,002 lebih kecil dari $\alpha=$ 0,025. Maka Ho ditolak Ha diterima artinya Return On Assets terdapat pengaruh signifikan dan positif secara parsial terhadap laba bersih pada perusahaan perkebunan di Bursa Efek Indonesia periode 2014 - 2018.

\section{Koefisien Determinasi $\left(R^{2}\right)$}

Berdasarkan Tabel 3 menunjukan bahwa R Square sebesar 0,347 yang artinya variabilitas variabel dependen yang dapat dijelaskan oleh variabel inndependen yaitu cash ratio, debt to equity ratio, return on assets dalam penelitian ini sebesar 34,70\% sedangkan sisanya 65,30\% dijelaskan variabel lain diluar model penelitian.

\section{Regresi Moderasi}

Tabel 4

Regresi Moderasi

\begin{tabular}{|c|c|c|c|c|c|}
\hline \multirow{2}{*}{ Model } & \multicolumn{2}{|c|}{ Unstandardized Coefficients } & \multirow{2}{*}{$\begin{array}{c}\text { Standardized Coefficients } \\
\text { Beta }\end{array}$} & \multirow{2}{*}{$\mathrm{t}$} & \multirow{2}{*}{ Sig. } \\
\hline & $\mathrm{B}$ & Std. Error & & & \\
\hline (Constant) & -.021 & .159 & & -.129 & .898 \\
\hline CashRatioXNilaiTukar & .184 & .187 & .170 & .981 & .336 \\
\hline DERXNilaiTukar & -.225 & .154 & -.221 & -1.466 & .155 \\
\hline ROAXNilaiTukar & -.144 & .152 & -.177 & -.948 & .352 \\
\hline
\end{tabular}

Sumber: data olahan 
Yunan Surono dan Andrian Hadinata, Pengaruh Cash Ratio, Debt to Equity Ratio, dan Return On Assets Terhadap Return Saham dengan Nilai Tukar sebagai Variabel Moderating Pada Perusahaan Perkebunan yang Terdaftar di Bursa Efek Indonesia (BEI) Periode 2014-2018

Pengujian nilai tukar (Z) sebagai pemoderasi pengaruh Cash Ratio (X1), Debt to Equity Ratio (X2), Return On Assets (X3), terhadap Return Saham (Y) menunjukan nilai signifikan secara berurutan sebesar 0,336, 0,155, dan 0,352, signifikan tersebut lebih besar dari nilai $\alpha=0,025$, maka nilai tukar tidak mampu secara segnifikan memoderasi Cash Ratio (X1), Debt to Equity Ratio (X2), Return On Assets (X3), terhadap Return Saham (Y). Berdasarkan hasil pengujian Moderate Regression Analysis pada masing-masing variabel independen menunjukan nilai signifikan lebih besar dari 0,025 , maka $\mathrm{H}_{3}$ tidak terdukung dan dapat dinyatakan nilai tukar tidak mampu secara segnifikan memoderasi pengaruh Cash Ratio, Debt to Equity Ratio, Return On Assets, terhadap Return Saham.

\section{Simpulan}

Berdasarkan hasil analisis diatas maka peneliti menarik kesimpulan sebagai berikut:

1. Hasil pengujian secara simultan seluruh variabel bebas berpengaruh segnifikan terhadap variabel terkait pada $\alpha=$ 5\% atau 0,05 dan kriteria uji $\mathrm{F}$ dengan membandingkan $F_{\text {hitung }}$ sebesar 4,607 dan $F_{\text {tabel }}$ sebesar 2,68, maka dapat dilihat bahwa $F_{\text {hitung }}>F_{\text {tabel }}$ yaitu 4,607 $>2,68$, artinya terdapat pengaruh segnifikan antara variabel cash ratio, debt to equity ratio, dan return on assets, secara simultan terhadap return saham pada perusahaan perkebunan periode 2014 - 2018. Serta berdasarkan pengujian koefisien determinasi menunjukan bahwa R Square sebesar 0,347 yang artinya bahwa variabilitas variabel dependen yang dapat dijelaskan oleh variabel independen yaitu cash ratio, debt to equity ratio san return on assets dalam penelitian ini adalah sebesar $34,70 \%$ sedangkan sisanya $65,30 \%$ dijelaskan variabel lain.

2. Hasil pengujian pada model regresi Nilai $t_{\text {hitung }}$ variabel Cash Ratio sebesar 0,166 dan $t_{\text {tabel }} 1,980$ dari hasil perbandingan maka dapat diketahui $t_{\text {hitung }}<t_{\text {tabel }}(0,166<1,980)$. Dapat dilihat dari signifikan Cash Ratio sebesar 0,869 lebih besar dari $\alpha=0,025$. Maka Ho diterima Ha ditolak artinya tidak ada pengaruh signifikan Cash Ratio secara parsial terhadap laba bersih. Dengan demikian, hasilnya tidak dapat digunakan untuk menunjukan bahwa cash ratio dapat mempengaruh return saham. Dari hasil perbandingan Nilai $t_{\text {hitung }}$ variabel Debt to Equity Ratio sebesar 2,348 dan $t_{\text {tabel }} 1,980$ dari hasil perbandingan maka dapat diketahui $t_{\text {hitung }}>t_{\text {tabel }}(2,348>1,980)$. Dapat dilihat dari signifikan Debt to Equity Ratio sebesar 0,027 lebih besar dari $\alpha=0,025$. Maka Ho ditolak Ha diterima artinya terdapat pengaruh secara signifikan Debt to Equity Ratio secara parsial terhadap return saham. Sedangkan hasil uji t terhadap model regresi Return On Assets terhadap Return Saham, dengan Nilai $t_{\text {hitung }}$ variabel Return On Assets sebesar 3,505 dan $t_{\text {tabel }} 1,980$ dari hasil perbandingan maka dapat diketahui $t_{\text {hitung }}>t_{\text {tabel }}(3,505>$ 1,980). Dapat dilihat dari signifikan Return On Assets sebesar 0,002 lebih kecil dari $\alpha=0,025$. Maka Ho ditolak Ha diterima artinya terdapat pengaruh signifikan Return On Assets secara parsial terhadap return saham pada perusahaan perkebunan di Bursa Efek Indonesia periode 2014 - 2018.

3. Berdasarkan hasil pengujian Moderate Regression Analysis pada masing-masing variabel independen menunjukan nilai signifikan secara berurutan sebesar 0,336,0,155, dan 0,352, signifikan tersebut lebih besar dari nilai $\alpha=0,025$, maka nilai tukar tidak mampu secara segnifikan memoderasi Cash Ratio (X1), Debt to Equity Ratio (X2), Return On Assets (X3), terhadap Return Saham (Y).

\section{Daftar Pustaka}

Amirullah dan Budiyono Haris. 2004. Pengantar Manajemen. Yogyakarta: Graha Ilmu

Anis, Sutriani. 2014. Pengaruh Profitabilitas, Leverage, Dan Likuiditas Terhadap Return Saham Dengan Nilai Tukar Sebagai Variabel Moderasi Pada Saham LQ-45. Journal of Business and Banking. Vol. 4, No. 1: 67-80.

Basuki, Agus Tri \& Prawoto, Nano. 2017. Analisis Regresi Dalam Penelitian Ekonomi \& Bisnis: Dilengkapi Aplikasi SPSS \& EVIEWS. PT Rajagrafindo Persada, Depok.

Bungin, Burham. 2013. Metodologi Penelitian Sosial dan Ekonomi: Format-Format Kuantitatif dan Kualitatif Untuk Studi Sosiologi, Kebijakan Publik, Komunikasi, Manajemen dan Pemasaran. Jakarta: Kencana.

Fahmi, Irham. 2017. Analisis Kinerja Keuangan. Bandung: Alfabeta.

Fahmi, Irham dan Yovi Lavianti Hadi. 2009. Teori Portofolio dan Analisis Investasi Teori dan Soal Jawab. Bandung. Alfabeta.

Ghozali, Imam. 2013. Aplikasi Analisis Multivariate dengan Program IBM SPSS 21 Update PLS Regresi. Semarang: Badan Penerbit Universitas Diponegoro.

Harahap, Sofyan Syafri. 2013. Analisis Kritis Atas Laporan Keuangan. Jakarta: Rajawali.

Hartono, Jogiyanto. 2012. Teori Portofolio dan Analisis Investasi, Edisi ke tujuh. Yogyakarta. BPFE-Yogyakarta.

Hasibuan, Malayu. 2001. Manajemen Sumber Daya Manusia. Jakarta: PT Bumi Aksara.

Jannah, Lailatul, 2016, Skripsi: Pengaruh Kinerja Perusahaan terhadap Return Saham Dengan Nilai Tukar Sebagai Variabel Moderasi Pada Perusahaan LQ-45 Periode 2008-2014, STIE Perbanas, Surabaya. 
Yunan Surono dan Andrian Hadinata, Pengaruh Cash Ratio, Debt to Equity Ratio, dan Return On Assets Terhadap Return Saham dengan Nilai Tukar sebagai Variabel Moderating Pada Perusahaan Perkebunan yang Terdaftar di Bursa Efek Indonesia (BEI) Periode 2014-2018

Kasmir. 2015. Analisis Laporan Keuangan. Jakarta: Rajawali Pers.

Margono. 2004. Metodologi Penelitian Pendidikan. Jakarta: Rineka Cipta.

Nurunnisak, Isnaini et al 2018, Skripsi: Analisis Rasio Profitabilitas, Leverage, dan Likuiditas Terhadap Return Saham Dengan Nilai Tukar Sebagai Variabel Moderating Studi empiris pada perusahaan manufaktur yang terdaftar di LQ 45 periode 2013 - 2016, Universitas Pandanaran, Semarang.

Sudana. I Made. 2015. Manajemen Keuangan Perusahaan, edisi dua. Jakarta. Erlangga

Sawaldjo, Puspopranoto. 2004. Keuangan Perbankan dan Pasar Keuangan. Jakarta : Pustaka LP3ES Indonesia.

Sartono, R. Agus. 2010. Manajemen Keuangan: Teori dan Aplikasi, edisi keempat. Yogyakarta. BPFE-Yogyakarta.

Sutrisno. 2013. Manajemen Keuangan: Teori, Konsep, dan Aplikasi. Yogyakarta. Ekonisia.

Susilo, Bambang D. 2009. Analisis Sekuritas. Yogyakarta. UPP STIM YKPN.

Sugiyono. 2017. Metode Penelitian Bisnis Pendekatan Kuantitatif, Kualitatif, Kombinasi, dan R\&D. Bandung: Alfabeta.

Silalahi, Ulber. 2018. Metodologi Analisis Data dan Interpretasi Hasil Untuk Penelitian Sosial Kuantitatif. Bandung. Refika Aditama.

Sunyoto, Danang. 2016. Metodologi Penelitian Akuntansi. Cetakan kedua. Bandung. Refika Aditama.

Umar, Husein. 2013. Metode Penelitian Untuk Skripsi dan Tesis Bisnis, edisi kedua. Jakarta. Rajagrafindo Persada. 